\title{
МЕТОДОЛОГІЧНІ ЗАСАДИ ДОСЛІДЖЕННЯ ДОКАЗУВАННЯ ОБСТАВИН, ЯКІ Е ПІДСТАВОЮ ДЛЯ ЗАСТОСУВАННЯ ЩОДО ЮРИДИЧНИХ ОСІБ ЗАХОДІВ КРИМІНАЛЬНО-ПРАВОВОГО ХАРАКТЕРУ
}

\author{
ПАНЬКО Мар'яна Свгенівна - асистент кафедри господарського права та \\ процесу Львівський торговельно-економічний університет
}

DOI:10.32782/EP.2020.2.18

В статье на основании анализа литературы по философби, билософии права, теории права, уголовного, уголовного процессуального права, теории доказввания въцелена система положений о методологии проведения исследований доказивания обстоятельств, являюшихся основанием для применения в отношении юридических лии мер уголовно-правового характера. Сформулированъ оптимальнъле подходъ в вылоре методологического инструментария организачии и осуществления процесса научного познания.

Ключевъие слова: метод, методология, мери уголовно-правового характера, доказивания, уполномоченное личо.

Постановка проблеми

Будь-яке наукове дослідження здійснюється за індивідуальними рисами у певній логічній послідовності та особливостями дослідника. Водночас можна виокремити деякі загальні підходи його проведення, які називають методологією (гр. methodos - спосіб, метод i $\log о$ - наука, знання), яка спирається на досягнення філософії, логіки, психології, наукознавства та розробляє методи, прийоми, засоби і способи виконання наукових робіт; встановлює принципи, норми, особливості і умови вирішення завдань; контролює дотримання черговості фаз, стадій та етапів здійснення науководослідної діяльності; регламентує взаємовідносини та взаємозв'язки між формами, засобами та методами вирішення завдань [1, c.58-59].
Методологія також дає змогу систематизувати увесь обсяг наукового знання й створити умови для розроблення подальших ефективних напрямів дослідження. Знання методології у науковому дослідженні дає змогу впорядкувати отримані результати, розкрити можливості пошуку альтернативних шляхів вирішення поставленої проблеми, оцінити практичну цінність отриманих результатів, розвинути здатність до ведення наукових дискусій та сформувати інтелектуальні здібності особистості дослідника [2, c.13, 15]. Водночас Н.В. Кушакова-Костицька вказує про необхідність перегляду підходу до методології правових досліджень. Зокрема, цей науковець зазначає, що методологічний підхід науковців у своїх дослідженнях стандартний і всім відомий (по закінченні свої роботи правознавець вимушений іноді вигадувати, а іноді перераховувати фактично застосовані методи). Тобто спочатку автор пише роботу, а потім, виходячи із ії змісту, формально перераховує ті методи, які йому відповідають [3, с. 24]. Така позиція безумовно є слушною, оскільки саме лише перерахування використаних методів у науковому дослідженні $є$ формальністю та створює так звану видимість використання відповідних гносеологічних засобів пізнання. Очевидно, що значення методології не можна недооцінювати, оскільки вона формує уявлення і дає оцінку способам обгрунтування наукового дослідження, створює систему наукової інформації та забезпечує всебічність їі отримання. Окрім того, внаслі- 


\section{Кримінальне право, кримінальний процес та криміналістика}

док правильного використанням основ методології, можна успішно вирішити поставлені завдання у науково-дослідній роботі та одержати науково-теоретичні результати, які мають значення не лише для науки, але й для правозастосовної діяльності.

\section{Стан дослідження}

Не можна оминути увагою праці тих авторів, які присвячені загальним положенням доказування у кримінальному провадженні, а зокрема: Р.С. Бєлкіна, В.В. Вапнярчука, I.В. Гловюка, В.Г. Гончаренка,Ю.М.Грошевого,А.В.Заклюка,О.В.Аитвина,А.О.Аяш, М.М.Михеєнка, М.А.Погорецького,С.М. Стахівського, О.О. Юхна, О.Г. Яновської та інших. На основі досліджень цих науковців сформовано сучасні уявлення про доказування як основну складову кримінальної процесуальної діяльності, яка покликана забезпечувати права та законні інтересів учасників кримінального провадження.

Слід згадати про дисертаційне дослідження О.В. Панченко, у якому автор з'ясувала місце кримінального провадження щодо юридичної особи в системі кримінального процесу України, визначила специфіку предмета доказування у цій частині, охарактеризувала особливості проведення процесуальних дій за участю юридичної особи, щодо якої здійснюється кримінальне провадження, під час досудового розслідування та судового провадження, а також проаналізувала підстави та процедуру застосування до юридичної особи заходів кримінально-правового характеру [4]. Не можна оминути увагою науково-методичні рекомендації К. А. Бугайчука, А. М. Ященка,I. В. Аєшукової, О. О. Кочура, А. В. Даниленка, що стосуються особливостей кримінального провадження щодо юридичної особи, у яких висвітлено загальні правила, підстави та порядок застосування до юридичних осіб заходів кримінально-правового характеру, а також проаналізовано особливості їх звільнення від застосування таких заходів [5]. Деякі праці висвітлюють тільки фрагментарно окремі питання, які пов’язані 3 доказуванням обставин, які є підставою для застосування щодо юридичних осіб за- ходів кримінально-правового характеру. Натомість, питання методологічних засад такого дослідження не розкрито жодним автором.

Таким чином, основною метою цієї статті є з'ясування особливостей методологічних засад дослідження доказування обставин, які є підставою для застосування щодо юридичних осіб заходів кримінально-правового характеру.

\section{Виклад основних положень}

Жодна наука не може розвиватися без постановки проблеми, ії чіткого формулювання та вирішення, яка $є$ одним із основних програмних компонентів наукового дослідження [6, с.32]. Не викликає заперечень той факт, що найбільшу складність становлять ті проблеми, формулювання та вирішення яких здійснюється 3 урахуванням декількох галузей права. Однією 3 таких проблем є наукове забезпечення практики доказування обставин, які є підставою для застосування щодо юридичних осіб заходів кримінально-правового характеру, вирішення якої потребує в основному залучення напрацювань як теорії кримінального процесу, так і кримінального права в цій частині. Так, постановка проблеми здійснюється з урахуванням вивчення наукових досліджень в галузях кримінального, кримінального процесуального, цивільного та адміністративного права; проведеного анкетування правоохоронних органів та суддів 3 досліджуваних питань доказування; аналізу судової практики шляхом вивчення кримінальних правопорушень, перелік яких передбачений у ст. 96-3 КК України, за результатами вчинення яких судом прийнято рішення про необхідність застосування щодо юридичної особи заходів кримінально-правового характеру.

При здійсненні розробки досліджуваної проблеми слід виходити із загальнометодологічних напрацювань філософської науки. Основою для реалізації завдань дослідження є положення гносеології та правового позитивізму. Так, гносеологію слід розглядати як вчення про можливість пізнання людиною предметів і явищ дійсності, їх власти- 
востей, зв'язків і відношень, про джерела, методи і закономірності пошуково-пізнавальної діяльності [7, с.13]. Отже, основною метою гносеологічних операцій є отримання нового знання про об'єкт. На основі цих теоретичних положень визначена можливість отримання достовірних знань про вчинювані кримінальні правопорушення уповноваженою особою від імені та в інтересах юридичної особи та діяльність правозастосовних органів 3 доказування обставин, які є підставою для застосування щодо юридичних осіб заходів кримінально-правового характеру на стадіях досудового та судового провадження із застосуванням методів чуттєвого та раціонального пізнання. Таким чином, під час доказування відбувається встановлення логічних зв'язків між подією кримінального правопорушення та його теоретичною моделлю.

У свою чергу, правовий позитивізм прийнято розглядати як систему поглядів на принципи правового регулювання відповідно до уявлень про догму права, співвідношення позитивного права з природнім правом людини [8, с. 186-200]. Ці положення нададуть можливість з'ясувати зміст кримінального та кримінального процесуального законодавства, в частині визначення підстав для застосування щодо юридичних осіб заходів кримінально-правового характеру, а також практики доказування відповідних обставин. У зв'язку з цим можна виокремити низку недоліків чинного законодавства, а відтак запропонувати відповідні зміни та доповнення до нього.

Окрім того, для здійснення дослідження базовими $\varepsilon$ положення діалектики, в основу якої покладено зв'язок теорії і практики, принципи пізнання реального світу, природи та мислення. Діалектичний підхід надасть змогу обгрунтувати причинно-наслідкові зв'язки, процеси диференціації та інтеграції, постійну суперечність між сутністю і явищем, змістом і формою, об'єктивність в оцінюванні дійсності [9, c.169]. Вказані положення нададуть можливість представити злочинну діяльність, спрямовану на вчинення злочинів, перелік яких передбачений ст. 96-3 КК України, від імені та (чи) в інтересах юридичної особи, та кримінальну процесуальну діяльність 3 доказування обставин, які $є$ підставою для застосування щодо юридичних осіб заходів кримінально-правового характеру як взаємопов'язані різновиди людської діяльності, суперечність цілей яких призводить до боротьби між їі суб'єктами.

Аналіз перспективних напрямів у розвитку сучасної методології показує, що розв'язання складних дослідницьких завдань передбачає використання нових стратегій наукового пошуку та принципово нових методів [10, с. 30]. Сучасна наука володіє потужним арсеналом різноманітних методів, які призначені для розв'язування різних за своїм характером наукових задач. При проведенні конкретного наукового дослідження використовуються ті методи, завдяки яким можна дати всебічну характеристику досліджуваного явища. Їх вибір залежить від мети і завдань дослідження, а також специфіки предмета пізнання [11, c.17]. Знання методів має величезне практичне й евристичне значення, оскільки орієнтує дослідника, допомагає йому вибрати істотне й виокремити другорядне, намітити шлях сходження від відомого до невідомого, від простого до складного, від вихідних посилок до висновків [12, с. 20]. Таким чином, вибір правильного методу має вагоме значення для успішності наукового дослідження, оскільки надає змогу ефективно вирішувати поставлені у ньому завдання та слугує, так би мовити, орієнтиром на шляху досягнення істини.

Обгрунтування напрямів і завдань дослідження, розробка та інтерпретація методу й алгоритму реалізації мети та завдань, обумовлює етапність безпосереднього його проведення, що відображатиме послідовність процесу роботи та його стратегію. Вбачається його здійснення у п'ять етапів наукового пошуку, які є взаємопов'язані та взаємодоповнюючі, однак, водночас, характеризуються індивідуальністю, оскільки відрізняються своїми цілями та завданнями, а також шляхами їх реалізації.

На першому, аналітико-ознайомлювальному етапі дослідження необхідно здійснити аналіз джерельної бази та стану розробленості теоретичних та практичних аспек- 


\section{Кримінальне право, кримінальний процес та криміналістика}

тів розглядуваної проблеми. До основних методів цього етапу слід відносити:

- пошуково-бібліографічний (пошук наукової літератури та нормативно-правової документації з питань, які стосуються теми дослідження за бібліографічними та електронними каталогами бібліотек України, а також їх аналіз, систематизація та узагальнення);

- порівняльно-правовий метод (на підставі аналізу чинного законодавства, юридичної літератури, методичних рекомендацій, узагальнень судової практики можна визначити прогалини в науковому забезпеченні питань доказування обставин, які є підставою для застосування щодо юридичних осіб заходів кримінально-правового характеру).

На другому, діагностично-пошуковому етапі дослідження необхідно сформулювати гіпотезу дослідження (обгрунтоване припущення про можливі засоби вирішення визначеної проблеми, яке є результатом глибокого усвідомлення теоретичних праць і досвіду практичної діяльності), без висунення якої подальше результативне його проведення неможливе. Кожну гіпотезу підтверджують фактами, які здобувають під час проведення наукового дослідження (це перетворює гіпотезу з припущення на достовірне знання). Щоб отримати факти підтвердження гіпотези, розробляють методику поетапного дослідження, яка має бути адекватною обраному предмету, відображати мету та завдання наукового пошуку [13, c. 28].

Таким чином, гіпотеза такого дослідження полягає в тому, що недостатня ефективність діяльності з доказування обставин, які є підставою для застосування щодо юридичних осіб заходів кримінально-правового характеру, обумовлена відсутністю належної законодавчої регламентації в цій частині. В iï основі покладена системна розробка рекомендацій 3 особливостей здійснення доказування обставин, які є підставою для застосування щодо юридичних осіб заходів кримінально-правового характеру, а також пропозицій про внесення змін щодо покращення стану чинного кримінального та кримінального процесуального законодавства, що сприятиме підвищенню ефективності діяльності співробітників оперативних підрозділів, слідчих, прокурорів та суддів в цій частині.

На третьому, концептуально-моделювальному етапі на основі діалектичного методу, системно-структурного аналізу, індукції, дедукції та методу моделювання доцільно розкрити розгорнутий план-конспект, у якому у стислому узагальненому вигляді відтворити актуальність теми, визначити об'єкт та предмет дослідження, конкретизувати його мету і завдання, методи вирішення, а також висвітлити структуру дослідження.

На четвертому, дослідному етапі дисертації з використанням герменевтичного та комплексного підходів необхідно провести аналіз теоретичного (вивчення нормативно-правових актів, наукової літератури) та емпіричного матеріалу (судової практики; результатів проведеного соціологічного дослідження), здійснити систематизацію й узагальнення результатів дослідження. На цьому етапі як основні методи повинні виступати наступні:

- методи аналізу і синтезу, логіко-семантичний метод. За їх допомогою доцільно конкретизувати структурні елементи поняття доказування як фундаментальної наукової правової категорії кримінального процесу, за результатами якого сформулювати поняття доказування обставин, які є підставою для застосування щодо юридичних осіб заходів кримінально-правового характеру. Окрім того, використання вказаних методів надасть можливість поглибити термінологічний апарат та розкрити зміст юридичних конструкцій «уповноважена особа», «вчинення злочину від імені юридичної особи», «вчинення злочину в інтересах юридичної особи» тощо, що має важливе практичне значення для доказування обставин, які $\epsilon$ підставою для застосування відповідних заходів щодо юридичних осіб;

- метод системного аналізу, системноструктурний та формально-логічний методи надасть можливість з'ясувати підстави та процесуальний порядок застосування щодо юридичних осіб заходів кримінально-правового характеру; обставини, які підляга- 
ють доказуванню в цій частині; підстави для звільнення юридичних осіб від застосування відповідних заходів; особливості доказування вказаних обставин на стадіях досудового та судового провадження;

- методи прогнозування та логіко-юридичний. Їх використання надасть змогу дослідити теоретичні і практичні засади доказування, сформулювати висновки, надати пропозиції щодо удосконалення чинного законодавства України та можливостей їх реалізації, забезпечити формулювання практичних рекомендацій в частині доказування обставин, які є підставою для застосування щодо юридичних осіб заходів кримінально-правового характеру, а також визначити їх вплив на підвищення продуктивності діяльності правозастосовних органів в цій частині;

- соціологічний метод. Дозволить шляхом узагальнень наукових позицій учених, результатів власних досліджень, а також проведення опитування у формі анкетування, встановити проблемні питання та віднайти шляхи їх вирішення з метою підвищення ефективності доказування обставин, які є підставою для застосування щодо юридичних осіб заходів кримінально-правового характеру;

- статистичний метод. 3 урахуванням цього методу вибір матеріалів судової практики необхідно здійснити за складами тих злочинів, за вчинення яких у встановленому законом порядку щодо юридичних осіб будуть застосовані заходи кримінально-правового характеру;

- метод експерименту. Завдяки його використанню буде здійснена апробація та впровадження результатів дослідження у правозастосовній діяльності та в навчальному процесі.

Нарешті, на п'ятому, завершальному етапі дослідження необхідно здійснити узагальнення одержаних результатів та обгрунтування висновків та рекомендацій щодо вдосконалення наукового забезпечення доказування обставин, які є підставою для застосування щодо юридичних осіб заходів кримінально-правового характеру. На цьому етапі, завдяки використанню методів узагальнення, систематизації, критично- го аналізу та системно-структурного, слід здійснити оцінку процесу виконання дослідження в частині підтвердження чи спростування висунутих гіпотез, та достовірності результатів, які відображені у висновках по роботі. Окрім того, підлягають з'ясуванню наступні питання: чи була реалізована мета та вирішені завдання дослідження; чи застосовувались усі необхідні методи під час його здійснення тощо.

\section{Висновки}

Таким чином, мета роботи і необхідні методичні передумови для іï досягнення охоплюють вивчення всіх аспектів наукового забезпечення доказування обставин, які є підставою для застосування щодо юридичних осіб заходів кримінально-правового характеру. Вони дозволять повно та всебічно здійснити вказане дослідження, виявити недоліки законодавчої регламентації в цій частині, одержати висновки, що мають наукове i практичне значення, а також обгрунтувати основні напрями і шляхи вдосконалення відповідної проблеми.

\section{Лiтература}

1. Шишкіна Є.К. Методологія наукових досліджень [Текст]: навч. посіб. / С.К. Шишкіна, О.О. Носирев. - Х.: Вид-во «Діса плюс», 2014. - 200 c.

2. Юринець В.С. Методологія наукових досліджень : навч. посібник / В. С. Юринець. - Львів : ЛНУ імені Івана Франка, 2011. $178 \mathrm{c}$.

3. Кушакова-Костицька Н.В. Методологічні проблеми сучасних правових досліджень : об'єктивна необхідність чи суб'єктивна формальність [Текст] / Н.В. Кушакова-Костицька // Філософські та методологічні проблеми права. - 2013. - №1-2. - C. 23-31.

4. Панченко О. В. Кримінальне провадження щодо юридичної особи: дис. ... канд. юрид. наук. Харків, 2018. 222 с.

5. Особливості кримінального провадження щодо юридичної особи : науковометодичні рекомендації / К. А.Бугайчук, А. М. Ященко, І. В. Аєшукова, О. О. Кочура, А. В. Даниленко. - Харків : ХНУВС, 2015. $-60 \mathrm{c}$. 


\section{Кримінальне право, кримінальний процес та криміналістика}

\section{АНОТАЦІЯ}

у статті на підставі аналізу літератури з філософиї, філософиї права, теорї права, кримінального, кримінального процесуального права, теорї доказування виокремлено систему положень про методологію проведення досліджень доказування обставин, які є підставою для застосування щодо юридичних осіб заходів кримінально-правового характеру. Сбормульовано оптимальні підходи щодо вибору методологічного інструментарію організаціі та здійснення процесу наукового пізнання.

Ключові слова: метод; методологія, заходи кримінально-правового характеру, доказування, уповноважена особа.

6. Керимов Д.А. Методология права (предмет, функции, проблемы философии права) / Д.А. Керимов. - [изд. 2-е.] - М.: Аванта, 2001. - 560 с.

7. Щедровицкий Г.П. Философия. Наука. Методология. [Текст] / Г.П. Щедровицкий - М.: Шк. культ. политики, 1997. - 656с.

8. Алексеев С.С. Право: Азбука - теория философия: Опыт комплексного исследования [Текст] / С.С. Алексеев. - М. : Инфра-М, 1998. - 820 c.

9. Чернілевський Д.В. Методологія наукової діяльності: Навчальний посібник: Вид. 2-ге, допов. / Д.В. Чернілевський, О.Є. Антонова, А.В. Барановська, О.В. Вознюк, О.А. Дубасенюк, В.І. Захарченко, І.М. Козловська, Ю.М. Козловський, К.О. Кольченко, М.І Аазарєв, Г.Ф. Нікуліна, В.О. Подоляк, А.В. Сліпчишина, О.В. Столяренко, М.І. Томчук, В.В. Шевченко, Н.В. Якса / За ред. професора Д.В. Чернілевського. - Вінниця: Видво АМСКП, 2010. - 484 с.

10. Пунченко О.П. Методологічні новації у сучасному науковому пізнанні / О.П. Пунченко // Гуманітарний вісник ЗДІА - №57 2014 p . - C.27-37

11. Еріна А.М. Методологія наукових досліджень: Навчальний посібник. / А.М. Ері-
The article, based on literature review for philosophy, philosophy of law, theory of law, criminal, criminal procedure law, theory of evidence, and experience in conducting research formulated the system of the provisions on the methodology of the research of proving circumstances that are founding for application to the legal entities.

Proposed and disclosed the contents of the stages of research. Reviewed the features of use the methods for the study: search and bibliographic, sociological, system-structural, modeling, statistical generalization, observation, analysis, synthesis, abstraction, formal logical, comparative law, experiment.

The question of whether scholar is obliged to use only defned structure of methods is discussed in philosophical legal literature. That is why necessity to decide what state of liberty in forming its own methodological structure has the researcher Optimal approaches in the choice of methodological tools of the organization and implementation of the process of scientific knowledge are formulated. As the result of scientifc research the next conclusions are made. First of all set of certain methods are mainly defined by the subject of the research.

While choosing research methods, first and foremost, the specifics of object of research have been taken into account. The set tasks have been completed on the basis of general philosophical, scientific and special methods. The abovementioned methods of scientific research have been used in conjunction consequently contributed to comprehensive analysis, grounding of theoretical conclusions and practical recommendations concerning

Key words: methods, methodology, measures criminal-law, proving, authorized person.

на, Б.В. Захожай, Д.ภ. Ерін. - К.: Центр навчальної літератури, 2004. - 212 с.

12. Колесников О. В. Основи наукових досліджень. 2-ге вид. випр.. та доп. Навч. посіб.- К.: Центр учбової літератури, 2011. -144 c.

13. Юринець В.С. Методологія наукових досліджень: навч. посібник / В. Е. Юринець. - Львів : ЛНУ імені Івана Франка, 2011. $178 \mathrm{c}$. 